\title{
Evaluation of oral care protocols practice by dentists in Rio de Janeiro towards HIV/ AIDS individuals
}

\author{
Carina Maciel Silva-Boghossian * (D, Brenda Azzariti Berrondo Boscardini, Claudia Maria Pereira and \\ Edson Jorge Lima Moreira
}

\begin{abstract}
Background: The aim of this study was to evaluate the dentists' knowledge and practice regarding HIV positive individuals' oral care in Rio de Janeiro State.

Methods: Dentists from Rio de Janeiro State $(n=242)$ answered an electronic questionnaire on biosafety procedures, oral manifestations of AIDS, and knowledge of HIV infection. Collected information was stratified by gender, and data were analyzed using Chi-square and $t$ tests.

Results: From the 14 oral manifestations investigated, oral candidiasis, necrotizing ulcerative gingivitis, and hairy leucoplakia were more associated with HIV, with no differences between the responses from men and women. Above $85 \%$ of the participants would be concerned about becoming infected with HIV after a needle/ sharp object injury and more than $80 \%$ of them were willing to be tested for HIV. However, significantly more women (98.8\%), compared to men (91.3\%), said they knew that HIV/ AIDS patients can contaminate dental care professionals, $p=$ 0.007. There was a significant difference in the answers for the questions: "Are there special dental clinics for treatment of HIV/AIDS patients in Brazil?" ( $p=0.044)$, and "Do the negative HIV tests surely indicate that the persons are free of viruses?" ( $p=0.005)$. Significant differences between men and women were also observed regarding use of disposable mask ( $p=0.01)$, and cap $(p<0.0001)$.
\end{abstract}

Conclusion: Most dentists who participated in the study presented a good knowledge on the care of HIV/ AIDS individuals, including biosafety protocols and in terms of the oral manifestations commonly associated to AIDS.

Keywords: Dental professional, Dentist, Oral health, HIV, AIDS

\section{Background}

After decades of its discovery, the human immunodeficiency virus (HIV) infection is still an alarming health public problem $[1,2]$. Infected individuals may develop the acquired immune deficiency syndrome (AIDS) when the infection reaches advanced stages [2]. In that condition, immunosuppression is measured through the evaluation of CD4+ lymphocytes as well as the counts of virus particles in carriers' blood. Levels of CD4+ bellow 200 $\mathrm{mg} / \mathrm{dL}$ indicates deficient immune response, which is one

\footnotetext{
* Correspondence: carinabogho@unigranrio.edu.br School of Dentistry, Postgraduate Program in Dentistry, University of Grande Rio (UNIGRANRIO), Rua Prof. Jose de Souza Herdy, 1160, Jardim 25 de Agosto, CEP, Duque de Caxias, RJ 25071-202, Brazil
}

important indicator for highly active antiretroviral therapy (HAART) initiation [3]. Due to HAART, currently, there are millions of people living with HIV in the world without AIDS symptoms [3-5]. However, non-symptomatic HIV+ individuals may still transmit the virus through sex without preservatives, shared needles, needle stick accident, pregnant women and even nursing mothers [5]. Therefore, routine screening tests for the identification of HIV infection is still necessary in order to avoid spreading of contamination [2].

Additionally, HIV+ individuals may have oral pathognomonic manifestations of AIDS, including oral candidiasis, hairy leucoplakia, Kaposi sarcoma, linear gingival erythema, necrotizing ulcerative gingivitis, necrotizing ulcerative periodontitis, and non-Hodgkin lymphoma [6-9].

(c) The Author(s). 2020 Open Access This article is distributed under the terms of the Creative Commons Attribution 4.0 International License (http://creativecommons.org/licenses/by/4.0/), which permits unrestricted use, distribution, and 
Those oral lesions may work as an indicator of infection progression [6-8]. Therefore, oral cavity clinical signs become extremely important for the primarily presumption for HIV infection [10]. In fact, dental surgeons may be the first health professionals to suspect of positivity [11].

Furthermore, during dental treatment, there is a considerable risk of cross-contamination [12]. Cross-infection may occur by accident with cutting or puncture contaminated material, for example, needle perforation [13]. Dental treatment sets are a perfect candidate place to occur crosscontamination due to saliva and blood sprays produced during treatment. However, it is worth to mention that the risk of HIV infection in that environment is reported to be very low, around $0.3 \%[14,15]$. Nonetheless, dentists must be well prepared to provide adequate attention to the increasing number of people living with HIV. In this scenario, it includes accurate diagnosis and treatment plan conducted under conditions that allow infection control [16]. Currently, there is no available information on dentists from Rio de Janeiro State on their knowledge on the care of individuals living with HIV/ AIDS. Thus, the aim of this study was to evaluate the dental surgeons' knowledge and practice regarding patient care towards HIV positive individuals.

\section{Methods}

This cross-sectional study was carried out from January to July 2018. Electronic questionnaire was developed in Google Forms, containing 47 questions, which included questions about dental care for HIV+ patients. The participants were dental surgeons regularly register in the Regional Council of Dentistry of Rio de Janeiro state (CRO$\mathrm{RJ})$. This study was submitted and approved by the Research Ethics Committee of Unigranrio (\# 2335672). Participants' consent was obtained automatically after they had read the Informed Consent form and agreed to access the survey by clicking on the link to the study questionnaire.

The electronic questionnaire was sent to about 6000 professionals registered at CRO-RJ to their email addresses. Details of the four parts of the questionnaire can be found in a previous work [17]. Furthermore, an English version of the questionnaire can be found as Additional file 1 .

\section{Data analysis}

All statistical tests used in the present study were performed with a statistical program (SPSS Statistics 20, IBM Brazil, São Paulo, Brazil). The distribution of specific responses on HIV+ patients were analyzed by grouping by gender. The tests used to evaluate significant differences between groups were $t$-test for independent samples and Chi-square. The level of significance established for all analyzes was $5 \%$.

\section{Results}

Table 1 presents demographic characteristics of the participants $(n=242)$. The majority of participants were female $(n=162 ; 67 \%)$. Women $(37.9 \pm 10.7$ years $)$ were significantly younger than men $(42.9 \pm 12.1 ; p=0.001$, T test). Professionals with a previous biomedical education other than Dentistry were $6.8 \%$ of women and $5 \%$ of mean. A significant difference in years of graduation from university was found between women 14.5 ( \pm 11.3) and men 18.4 ( \pm 11.1$), p=0.012$. Several participants had more than one dental specialization among the 21 areas cited. This accounted for $16 \%$ of women and $21.3 \%$ of men $(p=0.024$; Chi-square test). Most of the participants, $67.1 \%$ of women and $61.3 \%$ of men, worked in only one dental clinic.

Most participants answered 'yes' to the question 'Can HIV/AIDS individuals be diagnosed with oral lesions?', accounting for $82.7 \%$ of women and $75 \%$ of men (Table 2). Table 2 is also presenting participants' responses when they were asked if a list of oral manifestations were associated to HIV. Most part of answers were positive ('yes') for Kaposi's sarcoma (89.5\% of women and $90 \%$ of men), oral candidiasis (85.2\% of women and $82.5 \%$ of men), hairy leukoplakia (63\% of women and $60 \%$ of men) and necrotizing ulcerative gingivitis ( $71 \%$ of women and $62.5 \%$ of men). On the other hand, positive answers were below $50 \%$ for the remaining oral manifestations investigated. There was no significant difference in the distribution of answers between women and men.

Table 3 shows the distribution of answers related to professionals' knowledge on biosafety and the care of $\mathrm{HIV}+$ individuals. A significant number of professionals were worried about acquiring the virus after an accident with a contaminated sharp object $(87.7 \%$ of women and $85 \%$ of men). Most professionals would be willing to be tested for HIV after the accident (82.7\% of women and $80 \%$ of men). The majority have also said that dental professionals can be intermediate in the transmission of HIV ( $83.3 \%$ of women and $88.8 \%$ of men). Additionally, the majority said that medical care professionals are more prone to cross-infection related to HIV (98.8\% of women and $91.3 \%$ of men). Only $19.1 \%$ of women and $27.5 \%$ of men said that the HIV tests present a $100 \%$ specificity.

Table 4 presents the frequency of use of physical barriers according to gender. Although both groups do use mask with all patients (98.8\% of women; $92.5 \%$ of men), this was significantly different between them $(p=0.01)$. Most of the women (92\%) wear a cap during work, which was significantly higher than men $(48.8 \% ; p<0.0001)$. In terms of other means of physical protection (protection goggles; 1 pair of gloves that is changed between patients; 2 pairs of gloves that are changed between patients; autoclaved handpiece; disposable gown; and plastic wrap), no statistical difference was detected between genders. 
Table 1 Demographic characteristics of the study participants according to gender

\begin{tabular}{|c|c|c|c|}
\hline Variables & $\begin{array}{l}\text { Female } \\
(n=162)\end{array}$ & $\begin{array}{l}\text { Male } \\
(n=80)\end{array}$ & $P$ value \\
\hline Mean age in years ( \pm standard-deviation) & $37.9(10.7)$ & $42.9(12.1)$ & $0.001^{+}$ \\
\hline Degree in another biomedical profession (\%yes) & 6.8 & 5 & $>0.05$ \\
\hline Years of graduation from university ( \pm standard-deviation) & $14.5(11.3)$ & $18.4(11.1)$ & $0.012^{\dagger}$ \\
\hline \multicolumn{4}{|l|}{ Participants' specialty } \\
\hline$\cdot$ CBMF & 0.6 & 10 & \multirow[t]{23}{*}{$0.024^{*}$} \\
\hline - Restorative dentistry & 1.9 & 2.5 & \\
\hline$\cdot$ DTM & 0.6 & 0 & \\
\hline - Endodontics & 11.7 & 7.5 & \\
\hline - Estomatology & 1.2 & 1.3 & \\
\hline - Dental service management & 0 & 1.3 & \\
\hline - Implant dentistry & 4.9 & 3.8 & \\
\hline - Geriatric dentistry & 0.6 & 0 & \\
\hline - Work dentistry & 0 & 1.3 & \\
\hline - Hospital dentistry & 0.6 & 1.3 & \\
\hline - Legal dentistry & 0.6 & 1.3 & \\
\hline - Pediatrics dentistry & 14.2 & 3.8 & \\
\hline - Orthodontics & 10.5 & 5 & \\
\hline - Oral pathology & 0 & 1.3 & \\
\hline - Periodontics & 9.3 & 8.8 & \\
\hline - PNE & 0.6 & 0 & \\
\hline - Dental prosthesis & 3.7 & 11.3 & \\
\hline - Oral radiology & 0.6 & 1.3 & \\
\hline - Family health & 3.1 & 1.3 & \\
\hline - Public health & 0.6 & 1.3 & \\
\hline - Semiology & 0.6 & 0 & \\
\hline - More than one specialty & 16 & 21.3 & \\
\hline - No specialty & 17.9 & 15 & \\
\hline \multicolumn{4}{|l|}{ Work location (public or private service) } \\
\hline - Only one & 67.1 & 61.3 & \multirow[t]{3}{*}{$>0.05$} \\
\hline - More than one & 31.1 & 37.5 & \\
\hline - Do not work in clinical settings ${ }^{\ddagger}$ & 1.9 & 1.3 & \\
\hline
\end{tabular}

${ }^{*}$ Chi-square test; ${ }^{\dagger} \mathrm{T}$ test for independent samples; ${ }^{*}$ work in education, for example; CBMF oral and maxillofacial surgery, DTM temporomandibular joint dysfunction, NS non-significant, PNE special needs patients

Most respondents answered "No" to the question "Now, is AIDS the most important health problem in the world?" (75\% of women and $69.8 \%$ of men) (Fig. 1).

\section{Discussion}

AIDS still figures among the ten major and most important world health problems, despite all progress in the studies focusing on the virus and transmission prevention. Therefore, it is imperative that dental professionals have all possible knowledge towards HIV+ patients' care, mainly when it comes to cross contamination and pathogen dissemination. Having that in mind, the aim of the current investigation was to evaluate the level of dental care professionals' knowledge and practice in relation to HIV/AIDS individuals in the State of Rio de Janeiro, Brazil.

At the beginning of this study, it was possible to reach about 5000 dentists through their e-mails registered at the state dental council of Rio de Janeiro. However, only 242 of those professionals accepted to participate in the study, representing a low response rate $(4.8 \%)$. Nonetheless, it is still a comparable sample size to other studies $[13,18,19]$. In the study of Maia et al. [13], 170 dentists from Northeast Brazil were included; in Senna et al. 
Table 2 Distribution of answers on the professionals' knowledge regarding oral manifestations in HIV/ AIDS individuals

\begin{tabular}{|c|c|c|c|c|c|c|c|}
\hline \multirow[t]{3}{*}{ Oral manifestations } & \multicolumn{6}{|c|}{$\%$ answer } & \multirow{3}{*}{$\begin{array}{l}P \\
\text { value }\end{array}$} \\
\hline & \multicolumn{3}{|c|}{ Women $(n=162)$} & \multicolumn{3}{|c|}{ Men $(n=80)$} & \\
\hline & Yes & No & Do not know & Yes & No & Do not know & \\
\hline Can HIV/AIDS individuals be diagnosed with oral lesions? & 82.7 & 15.4 & 1.9 & 75 & 22.5 & 2.5 & $>0.05$ \\
\hline \multicolumn{8}{|l|}{ Are those manifestations related to HIV/AIDS? } \\
\hline - Kaposi's sarcoma & 89.5 & 6.2 & 4.3 & 90 & 8.8 & 1.3 & $>0.05$ \\
\hline - Oral candidiasis & 85.2 & 14.2 & 0.6 & 82.5 & 12.5 & 5 & $>0.05$ \\
\hline • Hairy leukoplakia & 63 & 20.4 & 16.7 & 60 & 26.3 & 13.8 & $>0.05$ \\
\hline - Periodontitis & 43.2 & 49.4 & 7.4 & 40 & 55 & 5 & $>0.05$ \\
\hline - Necrotizing ulcerative gingivitis & 71 & 21.6 & 7.4 & 62.5 & 28.8 & 8.8 & $>0.05$ \\
\hline - Herpes simplex & 48.8 & 45.1 & 6.2 & 48.8 & 47.5 & 3.8 & $>0.05$ \\
\hline - Major aphthous & 41.4 & 47.5 & 11.1 & 28.8 & 60 & 11.3 & $>0.05$ \\
\hline - Gingivitis & 36.4 & 54.3 & 9.3 & 33.8 & 63.8 & 2.5 & $>0.05$ \\
\hline - Cytomegalovirus & 44.4 & 25.3 & 30.2 & 51.3 & 31.3 & 17.5 & $>0.05$ \\
\hline • Herpes Zoster & 46.3 & 42 & 11.7 & 48.8 & 46.3 & 5 & $>0.05$ \\
\hline - Salivary gland infection & 25.9 & 53.1 & 21 & 25 & 61.3 & 13.8 & $>0.05$ \\
\hline • Lichen planus & 33.3 & 48.8 & 17.9 & 30 & 58.8 & 11.3 & $>0.05$ \\
\hline - Condiloma & 38.9 & 38.9 & 22.2 & 37.5 & 45 & 17.5 & $>0.05$ \\
\hline - Xerostomia & 29.6 & 56.8 & 13.6 & 21.3 & 70 & 8.8 & $>0.05$ \\
\hline
\end{tabular}

\section{*Chi-square test; NS non-significant}

Table 3 Distribution of professionals' answers on biosafety and dental care of HIV+ patients

\begin{tabular}{|c|c|c|c|c|c|c|c|}
\hline \multirow[t]{3}{*}{ Questions } & \multicolumn{6}{|c|}{ Distribution of answers (\%) } & \multirow{3}{*}{$\begin{array}{l}P \\
\text { value* }\end{array}$} \\
\hline & \multicolumn{3}{|c|}{ Women $(n=162)$} & \multicolumn{3}{|c|}{ Men $(n=80)$} & \\
\hline & Yes & No & $\begin{array}{l}\text { Do not know/ } \\
\text { Maybe }\end{array}$ & Yes & No & $\begin{array}{l}\text { Do not know/ } \\
\text { Maybe }\end{array}$ & \\
\hline \multicolumn{8}{|l|}{ After accident with a sharp object: } \\
\hline - Would you be worried to be infected? & 87.7 & 2.5 & 9.7 & 85 & 1.3 & 13.8 & $>0.05$ \\
\hline - Would you be tested for HIV? & 82.7 & 3.1 & 14.2 & 80 & 2.5 & 14.6 & $>0.05$ \\
\hline Can dental professionals act as an intermediary for transmission of HIV? & 83.3 & 14.2 & 2.5 & 88.8 & 10 & 1.3 & $>0.05$ \\
\hline Can patients with HIV/ AIDS contaminate dental professionals? & 98.8 & 1.2 & 0 & 91.3 & 8.8 & 0 & 0.007 \\
\hline Can needle stick injury transmit HIV? & 96.3 & 2.5 & 1.2 & 97.5 & 0 & 2.5 & $>0.05$ \\
\hline Are medical professionals more prone to cross-contamination? & 82.7 & 14.8 & 2.5 & 85 & 8.8 & 6.3 & $>0.05$ \\
\hline Can saliva be a vehicle for the transmission of AIDS? & 23.5 & 75.3 & 1.2 & 20 & 76.3 & 3.8 & $>0.05$ \\
\hline Is there a lot of HIV particles in the saliva of HIV/AIDS patients? & 14.2 & 64.8 & 21 & 15 & 66.3 & 18.8 & $>0.05$ \\
\hline Is hepatitis B more communicable than HIV/AIDS? & 81.5 & 9.3 & 9.3 & 86.3 & 5 & 8.8 & $>0.05$ \\
\hline Can CPR in patients with AIDS transmit HIV infection? & 12.3 & 71.6 & 16 & 17.5 & 76.3 & 6.3 & $>0.05$ \\
\hline $\begin{array}{l}\text { Do infection control methods for hepatitis B provide adequate } \\
\text { protection against the transmission of HIV? }\end{array}$ & 77.8 & 16 & 6.2 & 73.8 & 18.8 & 7.5 & $>0.05$ \\
\hline Are there special dental clinics for treatment of HIV/AIDS patients in Brazil? & 22.8 & 19.8 & 57.4 & 35 & 10 & 55 & 0.044 \\
\hline Do all sterilization methods have cidal effects against HIV? & 59.9 & 36.5 & 4.9 & 70 & 23.8 & 6.3 & $>0.05$ \\
\hline Can HIV be transmitted through aerosols by handpieces? & 19.1 & 61.7 & 19.1 & 21.3 & 62.5 & 16.3 & $>0.05$ \\
\hline $\begin{array}{l}\text { Do the negative HIV tests surely indicate that the persons are free of } \\
\text { viruses? }\end{array}$ & 4.9 & 92 & 3.1 & 16.3 & 83.8 & 0 & 0.005 \\
\hline Is Western blot a definite test for HIV/AIDS diagnosis? & 26.5 & 28.4 & 45.1 & 40 & 21.3 & 38.8 & $>0.05$ \\
\hline Is ELISA a screening test for HIV infection? & 83.3 & 3.7 & 13 & 76.3 & 6.3 & 17.5 & $>0.05$ \\
\hline Is the specificity of the HIV tests $100 \%$ ? & 19.1 & 61.1 & 19.8 & 27.5 & 52.5 & 20 & $>0.05$ \\
\hline
\end{tabular}


Table 4 Responses to measures of infection control of HIV transmission according to gender

\begin{tabular}{|c|c|c|c|c|c|c|}
\hline \multirow[t]{2}{*}{ Gender } & \multirow[t]{2}{*}{ Physical barrier } & \multicolumn{5}{|c|}{ Frequency of use (\%) } \\
\hline & & $\begin{array}{l}\text { Use with all } \\
\text { patients }\end{array}$ & $\begin{array}{l}\text { Use with some } \\
\text { patients }\end{array}$ & $\begin{array}{l}\text { Use just for some } \\
\text { procedures }\end{array}$ & $\begin{array}{l}\text { Do not } \\
\text { use }\end{array}$ & Others \\
\hline \multirow{8}{*}{$\begin{array}{l}\text { Women } \\
(n= \\
182)\end{array}$} & Mask * & 98.8 & 1.2 & 0 & 0 & - \\
\hline & Protection goggles & 69.8 & 6.2 & 13 & 7.4 & $3.7^{\dagger}$ \\
\hline & Cap ** & 92 & 3.1 & 3.7 & 1,2 & - \\
\hline & 1 pair of gloves - change between patients & 99.4 & 0.6 & 0 & 0 & - \\
\hline & $\begin{array}{l}2 \text { pairs of gloves - change between } \\
\text { patients }\end{array}$ & 21.3 & 10.6 & 11.9 & 56.3 & - \\
\hline & Autoclaved handpiece & 44.4 & 6.8 & 29.6 & 19.1 & \\
\hline & Disposable gown & 40.1 & 4.9 & 30.9 & 24.5 & - \\
\hline & Plastic wrap & 84 & 3.1 & 4.9 & 8 & - \\
\hline \multirow{8}{*}{$\begin{array}{l}\text { Men } \\
(n=80)\end{array}$} & Mask * & 92.5 & 0 & 2.5 & 3.8 & - \\
\hline & Protection goggles & 60 & 8.8 & 23.8 & 7.5 & 0 \\
\hline & Cap ** & 48.8 & 5 & 21.3 & 25 & - \\
\hline & 1 pair of gloves - change between patients & 98.8 & 0 & 1.3 & 0 & \\
\hline & $\begin{array}{l}2 \text { pairs of gloves - change between } \\
\text { patients }\end{array}$ & 29.5 & 7.7 & 7.7 & 55.1 & - \\
\hline & Autoclaved handpiece & 52.5 & 10 & 22.5 & 15 & \\
\hline & Disposable gown & 43.8 & 8.8 & 33.8 & 13.8 & - \\
\hline & Plastic wrap & 78.8 & 7.5 & 8.8 & 5 & - \\
\hline
\end{tabular}

${ }^{*} p=0.01$, and ${ }^{* *} p<0.0001$, Chi-Square test between genders. ${ }^{+}$Wear prescription glasses

[18], 140 dentists answered a questionnaire in another state capital. In the current investigation, most participants were women (66.9\%). A predominance of female participants $(64.3 \%)$ was also reported in other studies $[18,19]$.

More than $75 \%$ of participants know that HIV/ AIDS individuals can be diagnosed with oral manifestations. Moreover, most participants said that Kaposi's sarcoma
(89.5\% of women and $90 \%$ of men) and oral candidiasis (85.2\% of women and $82.5 \%$ of men) are oral signs of HIV/ AIDS. Those diseases seem to be the most known by dentists as related to HIV/ AIDS, as it was demonstrated by other studies [12, 20, 21]. In Oliveira et al. [20], 92.5 and $90.3 \%$ of participants said that Kaposi's sarcoma and oral candidiasis, respectively, are oral manifestations of HIV/ AIDS. Similarly, Oberoi et al. [21]

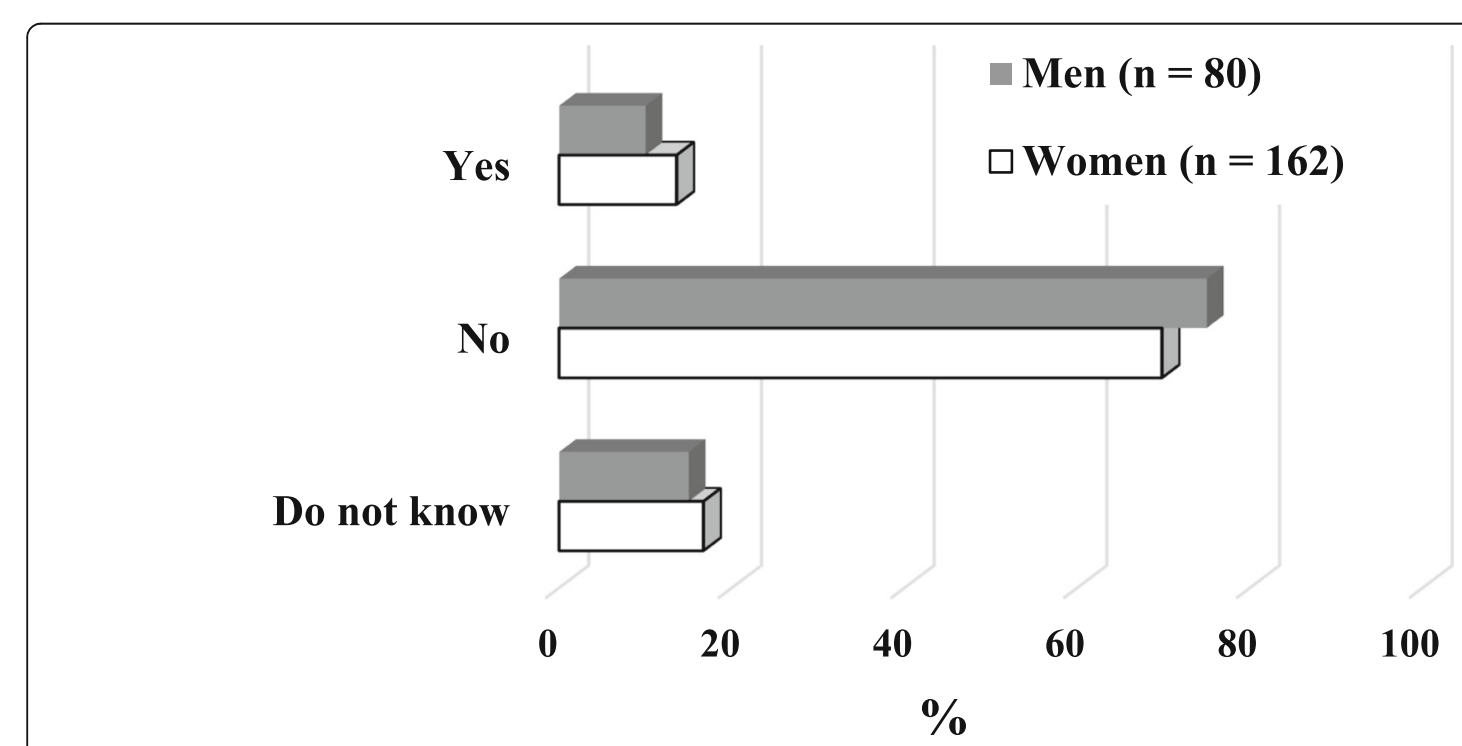

Fig. 1 Answers to "IS AIDS now the most important health problem in the world?" 
presented a percentage of "yes" of 95\% for oral candidiasis, $86 \%$ for Kaposi's sarcoma, $88 \%$ for necrotizing ulcerative gingivitis, $85 \%$ for hairy leukoplakia, $81 \%$ for Herpes zoster and major aphthous and $75 \%$ for salivary gland infection. In Sadeghi and Hakimi [12] work, several lesions were pointed out as associated to HIV/ AIDS. Interestingly, despite oral herpes simplex being an oral pathognomonic marker of HIV, current results showed a low rate of positive answers relating these lesions to HIV+.

Regarding accident with sharp objects, above $85 \%$ of the participants answered that HIV is transmitted via needle stick injury, which is in accordance with previous reports with dental students [10, 12, 17, 22, 23]. Nevertheless, this notion is not universal, as demonstrated by Aggarwal and Panat [24]. In the study of Rostamzadeh et al. [19] only $84 \%$ of the dentists affirmed that HIV/ AIDS prophylaxis is recommended after a needlestick injury.

Additionally, current data demonstrated that nearly $100 \%$ of individuals were worried of acquiring HIV after sharp object accident and would be taking a test afterwards. Those findings are a reflection of a great awareness on the existing risk in the injury with contaminated sharp objects [21, 25]. However, in another study [20], only $48 \%$ of participants said that they would be tested for HIV after a sharp object accident. Despite that low rate of concern with accidents, in Maia et al. [13] dentists presented major concerns in terms of work conditions in the care of HIV/ AIDS individuals. In that study, it was demonstrated that dentists who had continuous education towards HIV/ AIDS individuals' care might feel more confident to provide better care. Interestingly, a Canadian study showed that people living with HIV/ AIDS would prefer to be treated by dentists who are knowledgeable on the condition and with previous experience in treating carriers [26]. In fact, participants of that study believed that an increase in the knowledge and in the clinical experience may create an improved relationship between the patient and the professional.

In the current study, it was shown that disposable masks are used by almost every participant. The use of cap was significantly different between men and women. This could be explained by the fact that women are more worried with their hair contamination when there is a contaminated spray produced during handpiece use. In terms of using protection goggles, the current data is much higher to the ones reported by Oliveira et al. [20], in which $8 \%$ of women and $21 \%$ of men used it with all patients. Overall, current findings showed that the use of individual protection equipment were more frequent when compared to another study [19].

In general, current participants consider AIDS, nowadays, as not the most important health problem in the world. It is in accordance with other studies, in which $68 \%$
[12] and 65\% [24] of participants had similar answers. It is a fact that worldwide efforts on implementation of HAART have guaranteed longevity and quality of life to the ones living with HIV/ AIDS. Therefore, currently, it is not the most important health problem in the world. Nonetheless, it still is among the 10 major health problems in the world [5].

Not only is preventive approach a must in daily dental clinics, but it is also essential that dentists may be able to provide incipient diagnoses through the evaluation of oral cavity manifestations of HIV/AIDS. Ultimately, a good oral health will contribute for a good quality of life.

\section{Conclusion}

Most dentists who participated in the study presented a good knowledge on the care of HIV/ AIDS individuals, including biosafety protocols and in terms of the most common oral manifestations associated to AIDS.

\section{Supplementary information}

Supplementary information accompanies this paper at https://doi.org/10. 1186/s12903-020-0999-7.

Additional file 1. Questionnaire. Adaptation of the online questionnaire created on Google Forms and employed in the study.

\section{Abbreviations}

AIDS: Acquired immune deficiency syndrome; HAART: Highly active antiretroviral therapy; HIV: Human immunodeficiency virus

\section{Acknowledgements}

This work was presented as undergraduate course conclusion paper, and it was supported in part by National Foundation for the Development of Private Higher Education, Funadesp, Brasilia, Brazil.

\section{Authors' contributions}

BABB designed the project, collected, analyzed and interpreted obtained data and wrote draft. CMP analyzed and interpreted obtained data and wrote draft. EJLM collected data. CMS-B designed the project, collected, analyzed and interpreted obtained data, and wrote draft. All authors read and approved the final manuscript.

\section{Funding}

Author B.A.B.B. was supported with a student scholarship provided by National Foundation for the Development of Private Higher Education. This funding allowed her to design the project, collect, analyze and interpret obtained data and write a draft

\section{Availability of data and materials}

The datasets used and/or analyzed during the current study are available from the corresponding author on reasonable request.

\section{Ethics approval and consent to participate}

This study was submitted and approved by the Research Ethics Committee of Unigranrio (\# 2335672). Participants' consent was obtained automatically after they had read the Informed Consent form and agreed to access the survey by clicking on the link to the study questionnaire.

Consent for publication

Not applicable.

Competing interests

The authors declare that they have no competing interests. 
Received: 26 October 2019 Accepted: 3 January 2020

Published online: 14 January 2020

\section{References}

1. World Health Organization. HIV/ AIDS. Key facts. 2019. https://www.who.int/ news-room/fact-sheets/detail/hiv-aids. Acessed 7 Oct 2019.

2. UNAIDS. Joint United Nations Programme on HIV/AIDS. Ending AIDS Progress towards the 90-90-90 targets. GLOBAL AIDS UPDATE 2017. http:// www.unaids.org/sites/default/files/media_asset/Global_AIDS_update_2017_ en.pdf. Acessed 7 Oct 2019.

3. Ministério da Saúde. [Protocolo Clínico e Diretrizes Terapêuticas HIV/AIDS]. 2018. http://www.aids.gov.br/pt-br/profissionais-de-saude/hiv/protocolosclinicos-e-manuais. Acessed 7 Oct 2019.

4. UNAIDS. AIDSinfo Factsheets 2016. http://aidsinfo.unaids.org/. Acessed 7 Oct 2019.

5. UNAIDS. Joint United Nations Programme on HIV/AIDS. How to get to zero: Faster. Smarter. Better. World AIDS Day Report 2011. http://www.unaids.org/ sites/default/files/media_asset/JC2216_WorldAIDSday_report_2011_en_1. pdf. Acessed 7 Oct 2019.

6. Classification and diagnostic criteria for oral lesions in HIV infection. ECClearinghouse on Oral Problems Related to HIV Infection and WHO Collaborating Centre on Oral Manifestations of the Immunodeficiency Virus. J Oral Pathol Med. 1993;22(7):289-91.

7. Feigal DW, Katz MH, Greenspan D, Westenhouse J, Winkelstein W Jr, Lang W, et al. The prevalence of oral lesions in HIV-infected homosexual and bisexual men: three San Francisco epidemiological cohorts. AIDS. 1991;5(5): 519-25

8. Greenspan JS. Sentinels and signposts: the epidemiology and significance of the oral manifestations of HIV disease. Oral Dis. 1997;3(Suppl 1):S13-7.

9. Tappuni AR, Fleming GJ. The effect of antiretroviral therapy on the prevalence of oral manifestations in HIV-infected patients: a UK study. Oral Surg Oral Med Oral Pathol Oral Radiol Endod. 2001;92(6):623-8.

10. Singh VP, Osman IS, Rahmat NA, Bakar NAA, Razak N, Nettem S. Knowledge and attitude of dental students towards HIV/AIDS patients in Melaka, Malaysia. Malays J Med Sci. 2017;24(3):73-82.

11. McLean AT, Wheeler EK, Cameron S, Baker D. HIV and dentistry in Australia: clinical and legal issues impacting on dental care. Aust Dent J. 2012;57(3): 256-70.

12. Sadeghi M, Hakimi H. Iranian dental students' knowledge of and attitudes towards HIV/AIDS patients. J Dent Educ. 2009;73(6):740-5.

13. Maia LA, Vieira-Meyer APGF, Nuto SAS, Morais APP, Menezes EAV. Atenção à saúde bucal das Pessoas que Vivem com HIV/Aids na perspectiva dos cirurgiões-dentistas. Saúde Debate. 2015;39(106):730-47.

14. Blignaut E. The role of the dental profession in the AIDS epidemic. J Dent Assoc S Afr. 1994;49(3):133-5.

15. HIV epidemic -- a global update. Excerpts from the UN world AIDS day report. Health Millions. 1998;24(1):3-5.

16. UNAIDS. Report on the Global AIDS Epidemic 20102010 [Sept-26-2019]. https://wwwunaidsorg/en/resources/documents/2010/20101123_ globalreport Acessed 7 Oct 2019.

17. Lorosa AH, Pereira CM, Hussne RP, Silva-Boghossian CM. Evaluation of dental students' knowledge and patient care towards HIV/AIDS individuals. Eur J Dent Educ. 2019;23(2):212-9.

18. Senna MI, Guimaraes MD, Pordeus IA. Factors associated with dentists' willingness to treat HIV/AIDS patients in the National Health System in Belo Horizonte, Minas Gerais, Brazil. Cad Saude Publica. 2005;21(1):217-25.

19. Rostamzadeh M, Afkhamzadeh A, Afrooz S, Mohamadi K, Rasouli MA. Dentists' knowledge, attitudes and practices regarding hepatitis $B$ and $C$ and HIV/AIDS in Sanandaj. Iran BMC Oral Health. 2018;18(1):220.

20. Oliveira ER, Narendran S, Falcao A. Brazilian dental students' knowledge and attitudes towards HIV infection. AIDS Care. 2002;14(4):569-76.

21. Oberoi SS, Sharma N, Mohanty V, Marya C, Rekhi A, Oberoi A. Knowledge and attitude of faculty members working in dental institutions towards the dental treatment of patients with HIV/AIDS. Int Sch Res Notices. 2014;2014: 429692.

22. Ellepola AN, Joseph BK, Sundaram DB, Sharma PN. Knowledge and attitudes towards HIV/AIDS amongst Kuwait University dental students. Eur J Dent Educ. 2011;15(3):165-71.

23. Hamid Albujeer AN, Shamshiri AR, Taher A. HIV/AIDS awareness among Iraqi medical and dental students. J Int Soc Prev Community Dent. 2015;5(5): 372-6.
24. Aggarwal A, Panat SR. Knowledge, attitude, and behavior in managing patients with HIV/AIDS among a group of Indian dental students. J Dent Educ. 2013;77(9):1209-17.

25. Oberoi SS, Marya CM, Sharma N, Mohanty V, Marwah M, Oberoi A. Knowledge and attitude of Indian clinical dental students towards the dental treatment of patients with human immunodeficiency virus (HIV)/ acquired immune-deficiency syndrome (AIDS). Int Dent J. 2014;64(6):324-32.

26. Brondani MA, Phillips JC, Kerston RP, Moniri NR. Stigma around Hiv in dental care: Patients' experiences. J Can Dent Assoc. 2016;82:g1.

\section{Publisher's Note}

Springer Nature remains neutral with regard to jurisdictional claims in published maps and institutional affiliations.
Ready to submit your research? Choose BMC and benefit from:

- fast, convenient online submission

- thorough peer review by experienced researchers in your field

- rapid publication on acceptance

- support for research data, including large and complex data types

- gold Open Access which fosters wider collaboration and increased citations

- maximum visibility for your research: over $100 \mathrm{M}$ website views per year

At BMC, research is always in progress.

Learn more biomedcentral.com/submissions 